\title{
Effects of dietary hydrochloric acid on voluntary food intake and metabolism of sheep in relation to the use of mineral acids as silage additives
}

\author{
By J. L. L'ESTRANGE aNd T. MCNAMARA* \\ Department of Agricultural Chemistry, University College \\ Dublin, Glasnevin, Dublin 9, Republic of Ireland
}

(Received 28 October 1974-Accepted 7 Fanuary 1975)

\begin{abstract}
I. In Expt 1, a pelleted grass-meal diet was supplemented with hydrochloric acid, added to the grass pellets before feeding, at five levels from o to $628 \mathrm{mmol} / \mathrm{kg}$ dry matter (DM). Each diet was offered ad lib. for $2 \mathrm{I} d$ to five sheep in a $5 \times 5$ Latin-square design.

2. Voluntary food intake decreased rectilinearly with increasing $\mathrm{HCl}$ supplementation $(P<0.001)$, to $42 \%$ of the control value for sheep on the high- $\mathrm{HCl}$ diet. The decrease in food intake was related both to dietary $\mathrm{pH}$ and to the extent of metabolic acidosis induced by the $\mathrm{HCl}$ treatment. Although the $\mathrm{pH}$ of rumen fluid decreased slightly with increasing $\mathrm{HCl}$ supplementation, effects of the $\mathrm{HCl}$ treatment on volatile fatty acid concentrations in rumen fluid were not significant $(P>0.05)$.

3. In Expt 2, palatability and metabolic effects of dietary $\mathrm{HCl}$ were studied by comparing its effect when mixed into the pelleted grass meal before feeding, with and without a supplement of an equivalent amount of sodium bicarbonate given intraruminally, or when $\mathrm{HCl}$ was given intraruminally while the sheep consumed pelleted grass meal alone. Each of the three treatments was given at two levels of $\mathrm{HCl}, 280$ and $560 \mathrm{mmol} / \mathrm{kg} \mathrm{DM}$. At each level of dietary $\mathrm{HCl}$ supplementation, the three treatments and the control diet (pelleted grass meal alone) were each given to four sheep, in a Latin-square design, for I I d.

4. At the low level of supplementation, $\mathrm{HCl}$, when mixed into the pelleted grass meal, reduced food intake by $17 \%$, this effect was not altered by $\mathrm{NaHCO}_{3}$ supplementation, but when $\mathrm{HCl}$ was given intraruminally food intake was not reduced. At the high level of $\mathrm{HCl}$ supplementation, food intake was reduced by about $40 \%$ by each method of $\mathrm{HCl}$ supplementation; and $\mathrm{NaHCO}_{3}$ supplementation did not appreciably alter the effect of $\mathrm{HCl}$ on food intake, but prevented metabolic acidosis associated with the $\mathrm{HCl}$ treatments. Food intakes for the low- $\mathrm{HCl}$ treatments were significantly higher than those for the high-HCl treatments $(P<0.0 \mathrm{I})$ and the level of dietary $\mathrm{HCl} \times$ treatment interaction was also significant $(P<0.0 \mathrm{I})$. DM digestibility, and the $\mathrm{pH}$ and volatile fatty acid concentrations of rumen fluid were not significantly affected by the different treatments.

5. It is concluded that at a low level of $\mathrm{HCl}$ supplementation the adverse effects of dietary $\mathrm{HCl}$ on voluntary food intake of sheep is determined by palatability associated with low dietary $\mathrm{pH}$, whereas at a high level of $\mathbf{H C l}$ supplementation the effect is determined by palatability and by a metabolic response.
\end{abstract}

It has been reported previously that supplementation of a pelleted grass-meal diet with the mineral acids, hydrochloric and sulphuric, and the acid salts, ammonium bisulphate and sodium bisulphate, in amounts similar to that used in the 'AIV' method of ensilage (Virtanen, 1933), caused an adverse effect on voluntary food intake of sheep (L'Estrange, Clarke \& McAleese, I969; L'Estrange \& Murphy, 1972). In the experiment described here the effects of mineral acids on food intake of sheep were further studied. $\mathrm{HCl}$ rather than sulphates was used, as the results of earlier work had indicated that with the latter a secondary factor affecting food intake was

* Present address: The Valuation Office, Department of Finance, 6 Ely Place, Dublin 2, Republic of Ireland. 
the sulphate content (L'Estrange, Upton \& McAleese, I972; Upton, L'Estrange \& McAleese, 1972).

The three most likely ways by which excess $\mathrm{HCl}$ in the diet may affect food intake are: (a) reduced palatability associated with dietary $\mathrm{pH} ;(b)$ a disturbance of metabolism in the rumen associated with a decrease in the $\mathrm{pH}$ of rumen fluid; $(c)$ a disturbance of the blood acid-base balance.

In a previous experiment (L'Estrange \& Murphy, I972) it was found that food intake of sheep decreased gradually for several days after the introduction of $\mathrm{HCl}$ into the diet. This suggests that a metabolic disturbance was more important than palatability in affecting food intake, if it is assumed that lowered palatability would have an immediate effect on food intake, but a metabolic disturbance would have a more gradual effect.

With reference to conditions in the rumen, it has been reported by Baile \& Mayer ( 1968 ) that the appetite satiety mechanism of ruminants involves a receptor on the lumen side in the reticulo-rumen. An effect of rumen fluid $\mathrm{pH}$ on voluntary food intake has been shown by Bhattacharya \& Warner (1967), who reported that for steers, intraruminal infusions of lactic, citric or phosphoric acids, sufficient to maintain the $\mathrm{pH}$ of rumen fluid at 0.6 units below control values, caused a 50-70\% reduction in food intake. It has been reported also by several workers (e.g. Montgomery, Schultz \& Baumgardt, 1963) that the adverse effect of volatile fatty acids (VFA) infused intraruminally is much greater when these are given as the free acids than when they are given as the neutral salts. There has not been an adequate explanation of this difference, but the absence of any effect of the free acids on the blood acid-base balance (Montgomery et al. 1963) suggests that it is probably associated with changing conditions in the rumen.

In the previous study with mineral acid-treated diets fed to sheep (L'Estrange \& Murphy, 1972), it was found that $\mathrm{HCl}$ caused only a very small change in the $\mathrm{pH}$ of rumen fluid and did not alter the concentrations of VFA in the rumen fluid. A more noticeable metabolic change caused by the acid treatment of the diet was its induction of a chronic form of metabolic acidosis in the sheep, which developed gradually for several days after the introduction of the acid-treated diet and which quickly disappeared when this diet was withdrawn. It was concluded, therefore, that the metabolic acidosis, rather than a disturbance of rumen conditions was more likely to be the cause of the reduction in food intake.

It seemed desirable, therefore, to study more fully the effect of $\mathrm{HCl}$ on food intake of sheep in relation to palatability, changes in rumen conditions and metabolic disturbance. It was hoped that the results would give further information about the mechanism by which mineral acids affect food intake of ruminants, and also help to clarify the general problem of low voluntary consumption of silage by ruminants.

In the first experiment the relationship between the level of $\mathrm{HCl}$ added to a pelleted grass-meal diet, and food intake and metabolic changes was studied. In the second experiment, palatability and metabolic effects of dietary $\mathrm{HCl}$ were studied separately, by comparing the effects of the acid when it was fed mixed into the pelleted grass 
Table I. Chemical composition ( $\mathrm{g} / \mathrm{kg}$ dry matter) of the pelleted grass meal given as the basal diet to sheep in Expts $\mathrm{x}$ and 2

Proximate analysis
Crude protein
Diethyl ether extract
Crude fibre
Ash
Nitrogen-free extract
Mineral content
Calcium
Magnesium
Sodium
Potassium
Chloride

\begin{tabular}{|c|c|}
\hline \multicolumn{2}{|c|}{ Batch* } \\
\hline a & $b$ \\
\hline $\begin{array}{r}184 \\
26\end{array}$ & $\begin{array}{r}147 \\
26\end{array}$ \\
\hline 188 & 240 \\
\hline 129 & 86 \\
\hline 473 & $40 \mathrm{r}$ \\
\hline $5 \cdot 8$ & $5 \cdot 6$ \\
\hline I'3 & $I \cdot 4$ \\
\hline $\begin{array}{r}2 \cdot 4 \\
28 \cdot 2\end{array}$ & $\begin{array}{r}2 \cdot I \\
3^{8 \cdot 1}\end{array}$ \\
\hline 18.1 & 15.1 \\
\hline
\end{tabular}

* Batch a was used for Expt $I$ and the first half of Expt 2 and batch $b$ was used for the second half of Expt 2.

meal or when it was given in solution intraruminally, and by studying also the effects of intraruminal administration of sodium bicarbonate on the intake of pelleted grass meal containing added $\mathrm{HCl}$. Preliminary reports of these studies have already been presented (L'Estrange, 1972; L'Estrange \& McNamara, 1973).

\section{MATERIALS AND METHODS}

Expt I

Animals. Five 2-year-old Cheviot wethers weighing about $50 \mathrm{~kg}$ were used and were housed in metabolism cages throughout the experiment. They were fitted with permanent rumen cannulas.

Treatments. A basal diet of pelleted grass meal, the composition of which is shown in Table I, was supplemented with $\mathrm{HCl}$ at five different levels: 0 , I57, 314, 470 and $628 \mathrm{mmol} / \mathrm{kg}$ dry matter (DM). Batches of the experimental diets were prepared by pouring $300 \mathrm{ml}$ of a solution containing the appropriate amount of $\mathrm{HCl}$ onto $2 \mathrm{~kg}$ pelleted grass meal in a plastic container and mixing thoroughly. The control diet was prepared by diluting the pelleted grass meal to the same extent using distilled water.

Procedure. The five diets were fed to five sheep in a $5 \times 5$ Latin-square design experiment. Each of the experimental diets was offered ad lib. for $2 \mathrm{I} \mathrm{d}$, followed by a $7 \mathrm{~d}$ recovery period when the control diet was offered ad lib., before the next dietary treatment. Food intake was recorded daily, and food residues were withdrawn and dried twice weekly for the measurement of DM intake. Distilled water was provided throughout the experiment and its intake was recorded.

Blood samples were taken from the jugular vein of each sheep at 14.00 hours on days $4,8,12,16$ and 20 of each treatment period for acid-base and mineral analysis. Rumen fluid samples were taken through the rumen cannulas at 10.00, 12.00, 14.00 
and $\mathrm{I} 6.00$ hours on days 3 and 17 of each period, for $\mathrm{pH}$ and VFA analysis, using the methods previously described by L'Estrange \& Murphy (1972).

\section{Expt 2}

Animals. Eight 2-3-year-old Cheviot wethers were used, including four animals which were fitted with permanent rumen cannulas and which had taken part in Expt I, and were housed in metabolism cages throughout the experiment.

Treatments. A basal diet of pelleted grass meal, the composition of which is shown in Table I, was supplemented with dietary $\mathrm{HCl}$ at two levels: 280 and $560 \mathrm{mmol} / \mathrm{kg}$ DM. At each level of dietary $\mathrm{HCl}$ there were four treatments, as follows: (A) $\mathrm{HCl}$ mixed into the pelleted grass meal before feeding by pouring $250 \mathrm{ml} 2 \mathrm{M}$ - or $4 \mathrm{M}-\mathrm{HCl}$ onto $2 \mathrm{~kg}$ pellets as in Expt I; (B) $\mathrm{HCl}$ given intraruminally through a stomach tube in four equal portions during the day while the sheep were offered the pelleted grass meal to which water had been added $\left(25^{\circ} \mathrm{ml} / 2 \mathrm{~kg}\right)$. The amount of $\mathrm{HCl}$ infused was based on the $\mathrm{DM}$ intake for the previous day; (C) $\mathrm{HCl}$ added to the pelleted grass meal as for treatment $\mathrm{A}$ but with $\mathrm{NaHCO}_{3}$ given intraruminally through a stomach pump in four equal portions during the day. The amount of $\mathrm{NaHCO}_{3}$ infused was equivalent to the amount of $\mathrm{HCl}$ intake for the previous day, calculated from $\mathrm{DM}$ intake; (D) control, i.e. the basal diet of pelleted grass meal to which water had been added $(250 \mathrm{ml} / 2 \mathrm{~kg}$ ).

Procedure. The four treatments at each level of dietary $\mathrm{HCl}$ were given to four sheep in a $4 \times 4$ Latin-square change-over design experiment. Two of the sheep in each 'Latin-square' were fitted with permanent rumen cannulas. Each of the experimental diets was given for $\mathrm{I} I \mathrm{~d}$, followed by a $3 \mathrm{~d}$ recovery period when they were given the control diet, before the next set of treatments. For each treatment the pelleted grass meal, with added $\mathrm{HCl}$ or water, was offered $a d$ lib. from 09.30 to 17.00 hours. Food intake was recorded daily throughout the experiment. In addition, on day 4 food intake was recorded at intervals during the day to study the treatment effect on the pattern of eating during the day. Urine and faeces were collected and sampled from the two non-fistulated animals in each 'Latin-square' as previously described (L'Estrange \& Murphy, 1972). The pH of urine was recorded daily and the composite samples of urine and faeces were kept for subsequent analysis. Rumen fluid samples were taken from the two fistulated animals in each 'Latin-square' at I0.00, I I.30 and I 5.00 hours on day I $\mathrm{I}$, and blood samples from the jugular vein were taken from the four sheep in each 'Latin-square' at $10.00,11.30$ and 15.00 hours on day 9 or 10 as previously described (L'Estrange \& Murphy, 1972).

\section{Analytical methods}

The procedures used for the analysis of the DM content of food and faeces; $\mathrm{pH}$ of blood, urine and rumen fluid; total carbon dioxide concentration for plasma and urine; base excess (BE) status of blood; calcium, magnesium and sodium contents of the food and serum, and $\mathrm{Ca}$ concentration for the urine, were those previously described (L'Estrange \& Murphy, I972). The chloride concentration for serum was determined by titration with silver nitrate using a Radiometer system (Radiometer 
A/S, 72 Emdrupvej, Copenhagen NV, Denmark) incorporating an automatic titration unit (type SBR 2) connected to a $\mathrm{pH}$ meter (type $\mathrm{pH} \mathrm{M}$ 26) with an $\mathrm{Ag}$ electrode (type $\mathrm{P} 4 \mathrm{Or}$ ) and a mercuric sulphate electrode (type $\mathrm{K}$ 601) coupled to an automatic burette (type ABU-I2). The $\mathrm{Cl}^{-}$content of the food was determined by the same method, using an extract obtained by mixing $0.3 \mathrm{~g}$ oven-dried food with $25 \mathrm{ml} \mathrm{r} \cdot 6 \mathrm{M}$-nitric acid.

\section{RESULTS}

\section{Expt $I$}

The five sheep remained apparently healthy throughout the experiment.

Live-weight changes. There was a significant treatment effect $(P<0.01)$ on liveweight gain during the experimental period (Table 2). Animals given the control diet and the diet with the low level of $\mathrm{HCl}$ supplementation gained weight, but those given the treatments with the higher intake of $\mathrm{HCl}$ lost weight; the amount increased progressively as the level of $\mathrm{HCl}$ supplementation increased.

$D M$ intake. DM intake was significantly affected by treatment $(P<0.01)$; intake decreased progressively as the level of supplementary $\mathrm{HCl}$ increased, reaching only $42 \%$ of the control value at the high level of $\mathrm{HCl}$ supplementation (Table 2). Intake, where affected, decreased progressively during the first $7 \mathrm{~d}$ of treatment and then was fairly constant. During the recovery period, food intake increased immediately after withdrawal of the $\mathrm{HCl}$-supplemented diets, although a slight and non-significant $(P>0.05)$ carry-over effect was found following the high levels of $\mathrm{HCl}$ supplementation (Table 2). The results shown in Table 2 also suggest that the rectilinear decrease in food intake as the level of dietary $\mathrm{HCl}$ increased, which was significant $(P<0.00 \mathrm{I})$, was closely paralleled to a corresponding decrease in dietary $\mathrm{pH}$.

Water intake. Daily water intake progressively decreased as the level of $\mathrm{HCl}$ supplementation increased; however, water intake/unit weight of food eaten was not significantly affected by $\mathrm{HCl}$ treatment (Table 2).

$p H$ and VFA content of rumen fuid. The mean $\mathrm{pH}$ of rumen fluid decreased as the level of dietary $\mathrm{HCl}$ increased from $6 \cdot 55$ for animals given the control diet to $6 \cdot 27$ for animals given the diet with the high level of $\mathrm{HCl}$ supplementation; however, the treatment effect was not significant $(P>0.05)$. There was no significant treatment effect $(P>0.05)$ on total VFA concentration, which averaged $94.6 \mathrm{mmol} / \mathrm{l}$ for the five treatments, or on the molar proportion of individual VFA which averaged for acetic, propionic, isobutyric, butyric, isovaleric, and valeric; 675, 159, 21, Ir 3,20 and I3 $\mathrm{mmol} / \mathrm{mol}$ total VFA respectively. Although $\mathrm{pH}$, total VFA concentrations and molar proportions of propionic, isobutyric and isovaleric acids were each significantly affected by time of sampling during the day $(P<0.01)$, the time of sampling $\times$ treatment interaction for each was not significant $(P>0.05)$.

Blood acid-base status. As the level of dietary $\mathrm{HCl}$ increased there was a gradual decrease in mean blood $\mathrm{pH}$, plasma $\mathrm{CO}_{2}$ concentration and blood BE status (Table 2). The treatment effect on blood $\mathrm{pH}$ was not significant $(P>0.05)$. Plasma $\mathrm{CO}_{2}$ concentration was significantly affected by treatment $(P<0.05)$, decreasing from a mean value of 28.0 (control) to $24.8 \mathrm{mmol} / \mathrm{l}$ for animals given the high- $\mathrm{HCl}$ treatment. 
总总兽

s

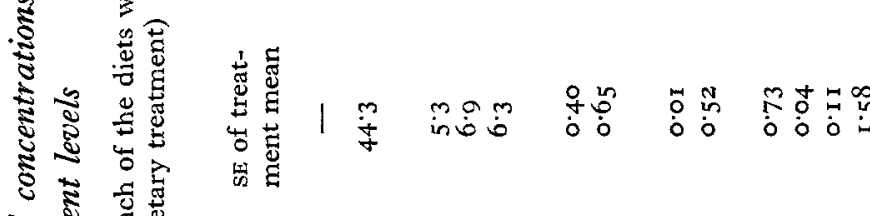

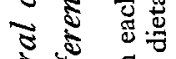

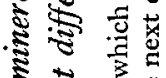

ปิ

ริ

$(\infty$

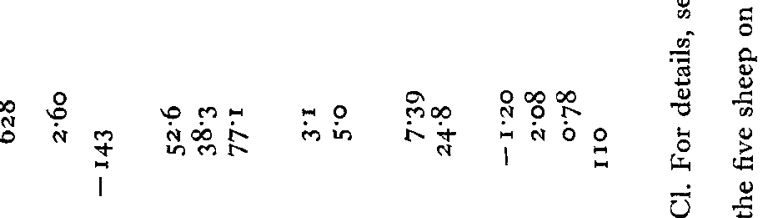

8.

군

8

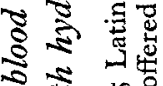

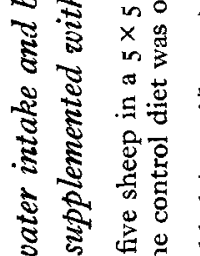

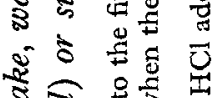

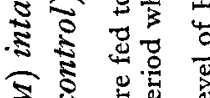

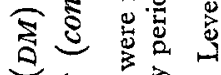

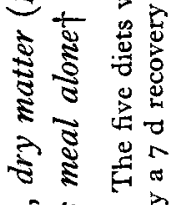

ธू

施

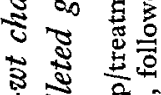

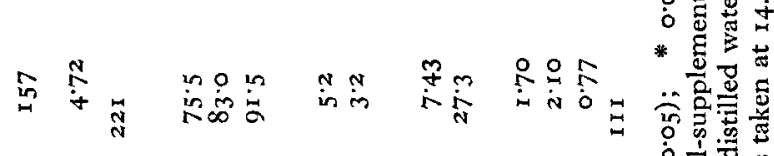

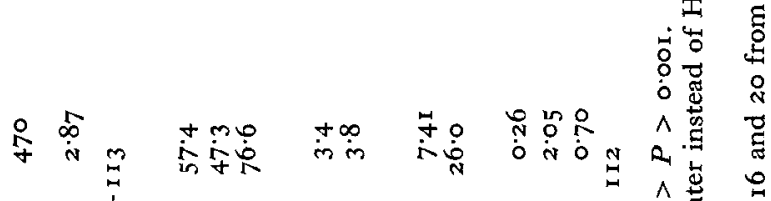

突

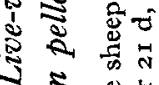

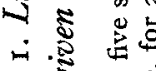

क्षे

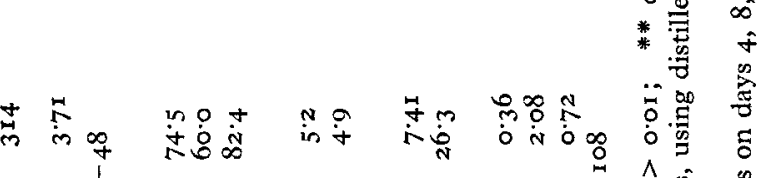

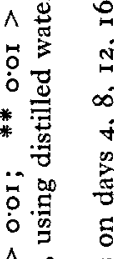

$\dot{\sim} \frac{8}{5}$

槅 ह

○尽N 
Blood $\mathrm{BE}$ status was also significantly affected by treatment $(P<0.01)$, decreasing from a mean value of $2 \cdot 16$ (control) to $-1 \cdot 2 \mathrm{mmol} / 1$ for animals given the high- $\mathrm{HCl}$ treatment. The day of sampling $\times$ treatment interaction was not significant for blood $\mathrm{pH}$, plasma $\mathrm{CO}_{2}$ concentration or blood BE status $(P>0.05)$. During the recovery period the values for these measurements returned to those for the control animals within $3 \mathrm{~d}$.

Mineral content of serum. There was no significant treatment effect on the concentration of $\mathrm{Ca}_{\text {or }} \mathrm{Cl}^{-}$for serum (Table 2). The concentration of $\mathrm{Mg}$ for serum was, however, significantly affected by $\mathrm{HCl}$ treatment $(P<\mathrm{O} \cdot \mathrm{OI})$, values generally decreasing as dietary $\mathrm{HCl}$ increased, except for animals given the high- $\mathrm{HCl}$ treatment (Table 2).

\section{Expt 2}

The eight sheep remained apparently healthy throughout this experiment.

DM intake. At the low level of supplementation $\mathrm{HCl}$, when mixed into the pelleted grass meal, caused a decrease in DM intake of $17 \%$ of the control value, an effect which was not appreciably altered by $\mathrm{NaHCO}_{3}$ supplementation (Table 3 ). However, at this level, $\mathrm{HCl}$ given intraruminally did not significantly affect $\mathrm{DM}$ intake. At the high level of supplementation, $\mathrm{HCl}$ mixed into the pelleted grass meal caused a decrease in intake of $48 \%$ of the control value, an effect which was not significantly altered by $\mathrm{NaHCO}_{3}$ supplementation. At this level of supplementation, $\mathrm{HCl}$ given intraruminally caused a decrease in DM intake of $42 \%$ of the control value. Over all the level of $\mathrm{HCl}$ supplementation, and the level of $\mathrm{HCl}$ supplementation $\times$ treatment interaction, each significantly affected food intake $(P<0.01)$.

Variation in daily food intake during the I I $\mathrm{d}$ on the control diet and on treatments where $\mathrm{HCl}$ was added to the pelleted grass meal was very similar to that for the same treatments in Expt $\mathrm{I}$. However, the intake of animals given intraruminal $\mathrm{HCl}$ at the high level fluctuated more widely, as the $\mathrm{HCl}$ intake for each day was based on DM intake on the previous day and consequently could be too high or too low in relation to the DM eaten on the same day. The pattern of eating during the day was similar for all treatments; approximately two-thirds of the food was eaten during the first $2.5 \mathrm{~h}$ of feeding, and the effect of treatment was fairly constant throughout the $7.5 \mathrm{~h}$ feeding period.

$D M$ digestibility. DM digestibility values for all treatments were higher than the control value, although the differences were not significant $(P>0.05)$ (Table 3$)$.

$p H$ and VFA contents of rumen fuid. The $\mathrm{pH}$ of rumen fluid (Table 3 ), which averaged $6 \cdot 45$ for all treatments, was not significantly affected by treatment, although the mean $\mathrm{pH}$ value obtained when $\mathrm{HCl}$ was given intraruminally at the high level was lower than that for the other treatments. Treatment effect on the total VFA concentration for rumen fluid was not significant $(P>0.05)$; the mean value for all treatments was $73 . \mathrm{Immol} / \mathrm{l}$. The molar proportions of individual VFA also were not significantly affected by treatment $(P>0.05)$, average values for all treatments for acetic, propionic and butyric acids were: 677,180 and $126 \mathrm{mmol} / \mathrm{mol}$ respectively. It should be noted, however, that as rumen fluid samples were taken from two animals only for 


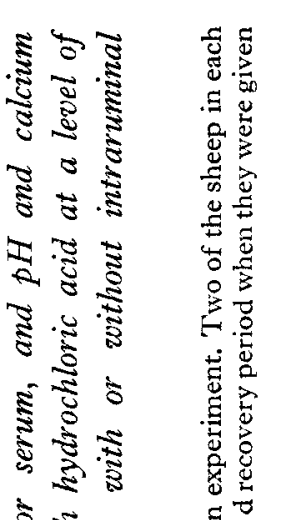
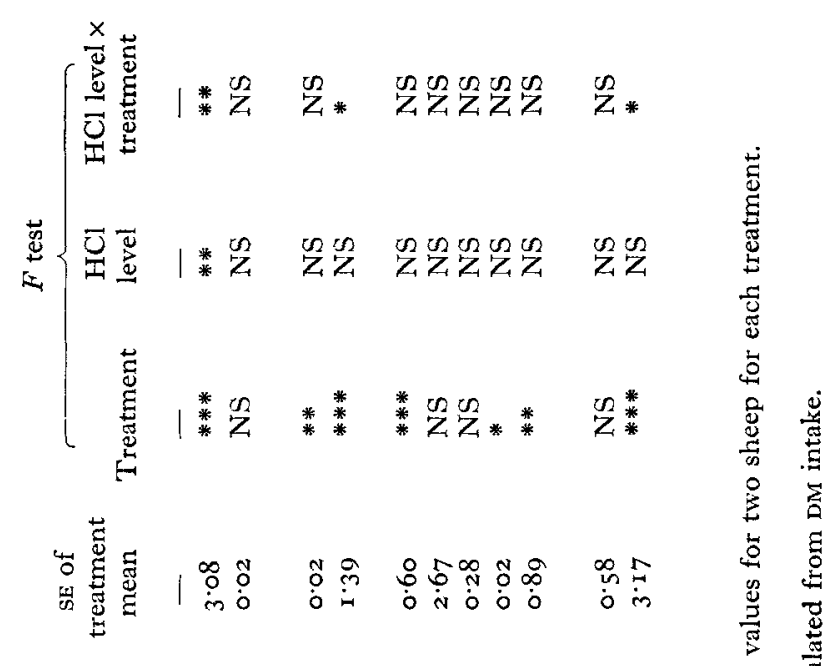

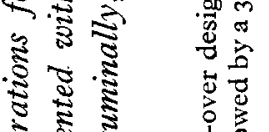

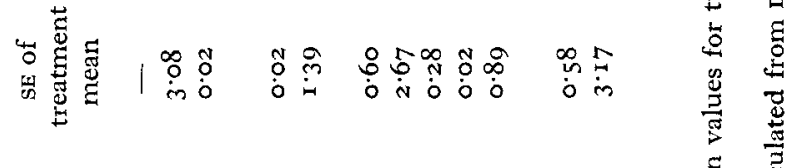

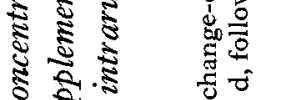

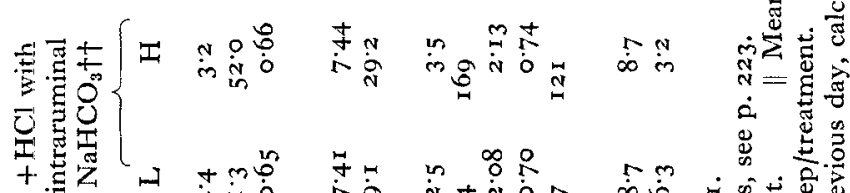

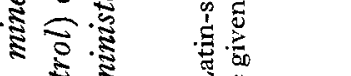

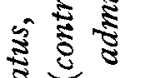

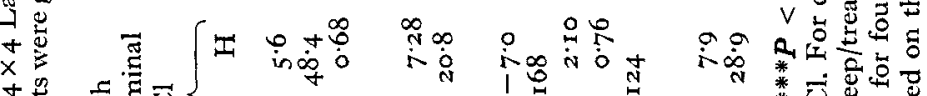

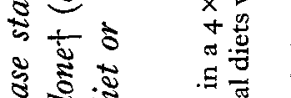
is

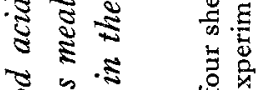

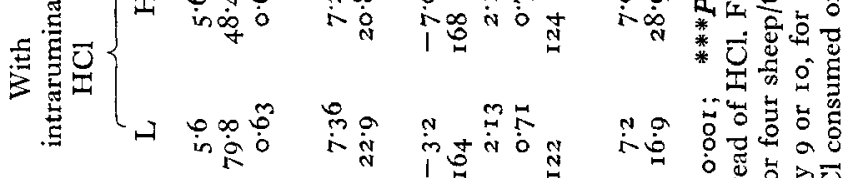
उั $2 \pi$ 焉

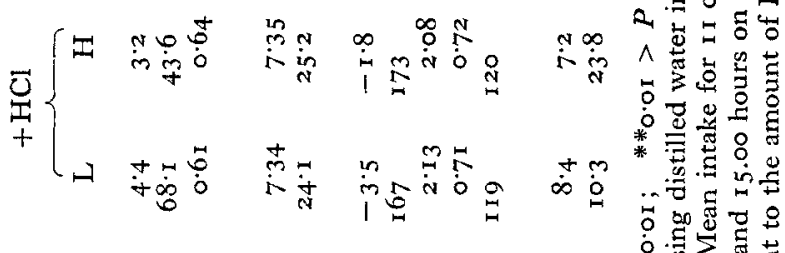

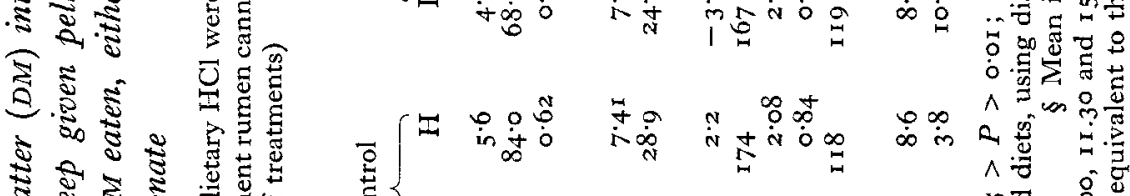

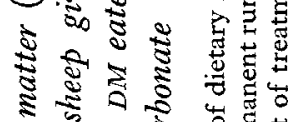
$\rightarrow \rightarrow$ के है के है. 岸 (⿸丆口

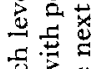

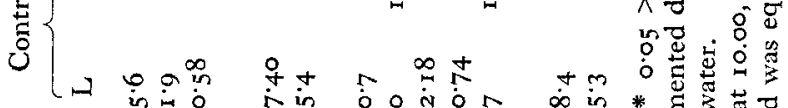

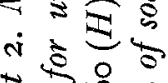
『ृ

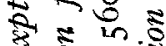
范苾

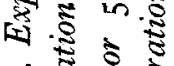

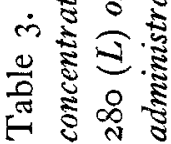

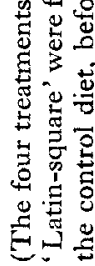

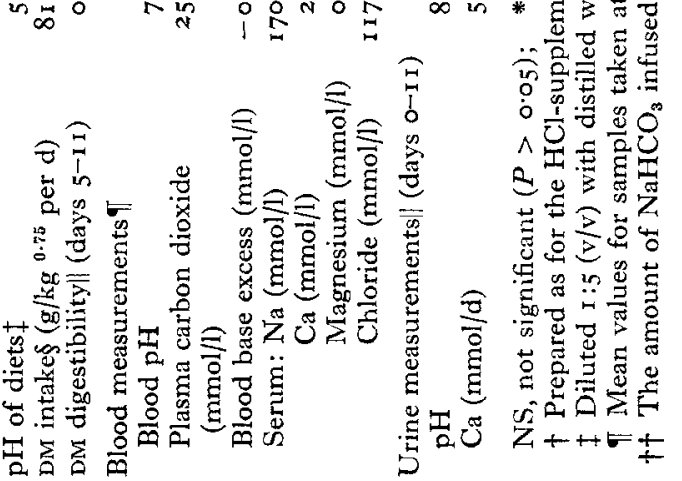


each treatment, the tests of significance for $\mathrm{pH}$ and VFA were not very sensitive. There was a significant 'time of sampling' effect on rumen fluid $\mathrm{pH}(P<0.01)$, average values for all treatments were $6.86,6.26$ and 6.31 at $10.00,11.30$ and I 5.00 hours respectively, but the time of sampling $\times$ treatment interaction was not significant $(P>0.05)$.

Blood acid-base status. With the low- $\mathrm{HCl}$ treatments metabolic acidosis developed in animals given $\mathrm{HCl}$ either mixed into the pelleted grass meal or intraruminally, although the effect of these treatments was significant $(P<0.0$ I $)$ only for plasma $\mathrm{CO}_{2}$ concentration and not for blood $\mathrm{pH}$ or blood $\mathrm{BE}$ status (Table 3 ). $\mathrm{NaHCO}_{3}$ supplementation prevented the development of acidosis. With the high- $\mathrm{HCl}$ treatments the extent of metabolic acidosis for animals given the $\mathrm{HCl}$ treatments was greater, particularly when $\mathrm{HCl}$ was given intraruminally; blood $\mathrm{pH}$, plasma $\mathrm{CO}_{2}$ concentration and blood $\mathrm{BE}$ status were all significantly affected by $\mathrm{HCl}$ treatment $(P<0.0 \mathrm{I})$. $\mathrm{NaHCO}_{3}$ supplementation again prevented the development of the acidosis. Over all, the level of $\mathrm{HCl}$ supplementation did not significantly affect blood $\mathrm{pH}$, plasma $\mathrm{CO}_{2}$ concentration or blood $\mathrm{BE}$ status $(P>0.05)$, while the level of $\mathrm{HCl}$ supplementation $\times$ treatment interaction was significant only for plasma $\mathrm{CO}_{2}$ concentration $(P<0.05)$. At each level of $\mathrm{HCl}$ supplementation the effect of time of sampling on blood $\mathrm{pH}$, plasma $\mathrm{CO}_{2}$ concentration and blood $\mathrm{BE}$ status was significant $(P<0.0 \mathrm{I})$; average values for all treatments at $10.00, \mathrm{I} 1.30$ and 15.00 hours were respectively: $\mathrm{pH} 7.40$, $7 \cdot 37$ and $7 \cdot 36$; plasma $\mathrm{CO}_{2}$ concentration $28 \cdot 0,25 \cdot 3$ and $24 \cdot 8 \mathrm{mmol} / 1$; blood $\mathrm{BE}$ status $+\mathrm{x} \cdot 43,-\mathrm{I} \cdot 78$ and $-\mathrm{I} \cdot 88 \mathrm{mmol} / \mathrm{l}$. Treatment differences were fairly consistent at each sampling time; a significant time of sampling $\times$ treatment interaction $(P<0.05)$ was obtained only for blood $\mathrm{pH}$ on the high- $\mathrm{HCl}$ treatments, where the treatment effect was greater at 15.00 hours.

Mineral content of serum. The $\mathrm{Cl}^{-}$concentration for serum was increased by $\mathrm{HCl}$ when given intraruminally; the effect was significant $(P<0.01)$ for the low- $\mathrm{HCl}$ treatments (Table 3 ). Serum levels for the other minerals studied, i.e. $\mathrm{Na}, \mathrm{Ca}$ and $\mathrm{Mg}$, were not significantly affected by treatment (Table 3 ).

Urine $\mathrm{pH}$ and Ca excretion. There was considerable variation between the two sheep in the effect of treatment on $\mathrm{pH}$ and excretion of $\mathrm{Ca}$ in urine (Table 3 ). The $\mathrm{pH}$ of urine was not significantly affected by treatment. Urinary Ca excretion was increased by $\mathrm{HCl}$ given in the diet or intraruminally $(P<0.001)$ while $\mathrm{NaHCO}_{3}$ supplementation restored values for $\mathrm{Ca}$ excretion to the control values. Over all the effect of the level of $\mathrm{HCl}$ supplementation on urinary $\mathrm{Ca}$ excretion was not significant $(P>0.05)$ but the level of $\mathrm{HCl}$ supplementation $\times$ treatment interaction was significant $(P<0.05)$. As urine samples were taken from only two animals for each treatment, these tests of significance were not very sensitive.

\section{DISCUSSION}

The results of Expt I confirm the previous finding (L'Estrange \& Murphy, 1972) that $\mathrm{HCl}$ when added to a pelleted grass-meal diet adversely affects voluntary food intake of sheep. The relationship between the level of dietary $\mathrm{HCl}$ and food intake was found to be almost rectilinear over the range studied. As in the previous study, 
food intake gradually decreased for about $7 \mathrm{~d}$ after the introduction of the mineral acid and then remained constant for the rest of the $2 \mathrm{I} d$ experimental period, increasing again to the control intake within a few days of withdrawal of the supplement.

$\mathrm{HCl}$ supplementation, even at the high level of $560 \mathrm{mmol} / \mathrm{kg}$ dietary DM, caused only a small and non-significant effect on the $\mathrm{pH}$ of rumen fluid and did not affect its total VFA concentration or the proportions of individual VFA, a result also in agreement with that of the previous experiment (L'Estrange \& Murphy, 1972). It appears therefore that the adverse effect of dietary $\mathrm{HCl}$ on food intake was not the result of a reduction in rumen $\mathrm{pH}$, as suggested for other acids by Bhattacharya \& Warner (1967). The most striking metabolic effect caused by $\mathrm{HCl}$ supplementation in Expt I was that it induced a chronic form of metabolic acidosis in the sheep, the extent of which, although related to the level of $\mathrm{HCl}$ supplementation, was not severe even at the highest level. The results were of the same order as previous results obtained for mineral acid supplementation for sheep (L'Estrange \& Murphy, 1972) and cattle (Lebeda, Bouda \& Kucěra (1970). Although the results for Expt I suggested a close relationship between the extent of metabolic acidosis and the reduction in food intake of the sheep, it was not possible to deduce from the results whether or not the acidosis was the direct cause of the reduction in food intake. A close relationship found between dietary $\mathrm{pH}$ and $\mathrm{DM}$ intake suggested that food intake was possibly determined by palatability associated with low dietary $\mathrm{pH}$.

In Expt 2 the attempt to separate palatability and metabolic effects of dietary $\mathrm{HCl}$ by comparing the effects of the $\mathrm{HCl}$ when mixed into the pelleted grass meal or given intraruminally proved quite successful. The reduction in food intake caused by each level of $\mathrm{HCl}$ when mixed into the pelleted grass meal without intraruminal administration of $\mathrm{NaHCO}_{3}$ was very similar to that found using similar amounts of $\mathrm{HCl}$ in Expt $\mathrm{r}$. However, when given intraruminally, the low level of $\mathrm{HCl}$ supplementation had no effect on food intake, indicating that the effect of $\mathrm{HCl}$ when added to the pelleted grass meal was determined by palatability rather than by a metabolic disturbance. This was further substantiated by the results obtained for $\mathrm{NaHCO}_{3}$ administration when the HCl-treated diet was fed, which, although preventing the development of metabolic acidosis, did not increase food intake to control levels.

The results obtained for the high level of $\mathrm{HCl}$ supplementation suggest that food intake was determined both by palatability and by a metabolic disturbance. The reduction in food intake caused by $\mathrm{HCl}$ was similar whether it was mixed into the pelleted grass meal or given intraruminally. The finding that the administration of $\mathrm{NaHCO}_{3}$ when feeding the $\mathrm{HCl}$-treated diet (which prevented the development of metabolic acidosis and decrease in $\mathrm{pH}$ of rumen fluid) caused only a small and nonsignificant increase in food intake, confirmed the importance of palatability in determining food intake at the high level of $\mathrm{HCl}$ supplementation also. From previous studies of the effect of $\mathrm{NaCl}$ supplementation on food intake of sheep (L'Estrange et al. 1972), the palatability effect of $\mathrm{HCl}$ was probably caused by the low $\mathrm{pH}$ of the diets rather than by the increase in $\mathrm{Cl}^{-}$content per se. It is, however, somewhat surprising to find that a reduction in dietary $\mathrm{pH}$ to a value of 4.4 may have this effect on food intake. From this result it may be speculated that, with silages made 
without added mineral acids, the positive correlation found between $\mathrm{pH}$ and voluntary intake of the silage by sheep (Wilkins, Hutchinson, Wilson \& Harris, 1971; Brown \& Radcliffe, 1972) is a palatability response to dietary $\mathrm{pH}$. In addition, for cattle and sheep, the increase in consumption brought about by neutralization with $\mathrm{NaHCO}_{3}$ of silage made without added inorganic acid (Orth \& Kaufmann, 1966; McLeod, Wilkins \& Raymond, 1970) may be due to improved palatability associated with the increase in $\mathrm{pH}$.

The results from Expt 2 for DM digestibility and for $\mathrm{pH}$ and VFA concentrations of rumen fluid were inconclusive as only two animals were sampled for each treatment. However, there appeared to be no adverse effect on DM digestibility or on VFA production in the rumen by any of the treatments relative to the control, a result in agreement with that of previous studies when $\mathrm{HCl}$ was given mixed with the diet (L'Estrange \& Murphy, 1972).

In Expt 2, urine samples were also taken from two sheep per treatment only. Unexpectedly, in view of previous results (L'Estrange \& Murphy, 1972), urinary $\mathrm{pH}$ was not consistently reduced by dietary $\mathrm{HCl}$ at each level of supplementation. However, urinary $\mathrm{Ca}$ excretion, particularly at the high level of supplementation, was substantially increased by $\mathrm{HCl}$, in agreement with previous results. This effect was largely overcome by $\mathrm{NaHCO}_{3}$ administration, which also restored the blood acid-base balance. An explanation of the results for urinary $\mathrm{pH}$ for this experiment is not readily apparent. Possibly the restriction of food consumption to $7.5 \mathrm{~h} / \mathrm{d}$ may have caused diurnal variation in urinary acid-base excretion which could mask treatment differences measured over the $24 \mathrm{~h}$ period.

The authors are indebted to Mr D. B. R. Poole and Dr P. A. M. Rogers, An Foras Taluntais, Dunsinea, Republic of Ireland, for rumen cannulation of experimental animals, and thank also Mr M. Caffrey, Mr S. Dillon and Miss K. McCormack for skilled technical assistance.

\section{REFERENCES}

Baile, C. A. \& Mayer, J. (r968). F. Dairy Sci. 51, 1490.

Bhattacharya, A. N. \& Warner, R. G. (r967). \%. Dairy Sci. 5o, 1 I 6 .

Brown, D. C. \& Radcliffe, J. C. (1972). Aust. F. agric. Res. 23, 25.

Lebeda, M., Bouda, J. \& Kucěra, A. (I 970). Acta vet., Brno 39, 415.

L'Estrange, J. L. (r972). Proc. Br. Soc. Anim. Prod. p. I48.

L'Estrange, J. L., Clarke, J. J. \& McAleese, D. M. (1969). Ir. F. agric. Res. 8, r33.

L'Estrange, J. L. \& McNamara, T. (1973). Ir. Grassld Anim. Prod. F. 7, I 52.

L'Estrange, J. L. \& Murphy, F. (1972). Br. F. Nutr. 28, I.

L'Estrange, J. L., Upton, P. K. \& McAleese, D. M. (I972). Ir. F. agric. Res. Ir, I 27.

McLeod, D. S., Wilkins, R. J. \& Raymond, W. F. (1970). F. agric. Sci., Camb. 75, 3 I r.

Montgomery, M. J., Schultz, L. H. \& Baumgardt, B. R. (1963). F. Dairy Sci. 46, 138o.

Orth, A. \& Kaufmann, W. (1966). Z. Tierphysiol. Tierernähr. Futtermittelk. 21, 350.

Upton, P. K., L'Estrange, J. L. \& McAleese, D. M. (1972). Ir. F. agric. Res. II, I45.

Virtanen, A. J. (1933). Emp. F. exp. Agric. 1, 143.

Wilkins, R. J., Hutchinson, K. J., Wilson, R. F. \& Harris, C. E. (1971). F. agric. Sci., Camb. 77, 531. 